American Journal of Environmental Sciences 7 (5): 402-408, 2011

ISSN 1553-345X

(C) 2011 Science Publications

\title{
Assessment of Lead and Cadmium Content in the Soils and Plants in Industrial Area
}

\author{
${ }^{1}$ Gabriela Oprea, ${ }^{1}$ Cristina Mihali, ${ }^{2}$ Angela Michnea, \\ ${ }^{3}$ Marin Senila, ${ }^{4}$ Ionel Gogoasa and ${ }^{1}$ Zorica Vosgan \\ ${ }^{1}$ Department of Chemistry and Biology, Faculty of Sciences, \\ North University of Baia Mare, 430083, Romania \\ ${ }^{2}$ Environmental Protection Agency Maramureş, 1A Iza Street, 430073 Baia Mare, Romania \\ ${ }^{3}$ Institute of National Research and Development, 67 Donath Street, 400293 Cluj-Napoca, Romania \\ ${ }^{4}$ Department of Chemistry, Faculty of Food Processing Technology, Banat's University of Agriculture \\ Science and Veterinary Medicine, 119 Aradului Road, Timişoara, RO-300645, Romania
}

\begin{abstract}
Problem statement: The objective of this research was to assess the degree of soil pollution and also of Plant contamination with lead $(\mathrm{Pb})$ and cadmium $(\mathrm{Cd})$ in Baia Mare city (located in NW Romania) area which used to be one of the most important nonferrous metallurgical centers in Romania. Approach: Soil and plant samples were collected from 3 districts of Baia Mare: Ferneziu, located near the metallurgical plant producing lead, Săsar district, along the Săsar River in the preferential direction of the wind blowing from the metallurgical plant and the central area (Center) of the city of Baia Mare. As reference area, Dura area was considered located in a less polluted zone. The $\mathrm{Pb}$ and $\mathrm{Cd}$ assay was carried out by inductively coupled plasma atomic emission spectrometry. Statistical analysis of the data was performed and correlations and similarities between the variables were highlighted. Principal component analysis was applied in order to improve the significance and to reduce the number of variables. Results: The highest contents of $\mathrm{Pb}$ and $\mathrm{Cd}$ both in soil and in plants were found in Ferneziu district where $\mathrm{Pb}$ average content in soil was $4400 \mathrm{mg} \mathrm{kg}^{-1}$ Dry Weight (DW) at $0-10 \mathrm{~cm}$ depth and $3100 \mathrm{mg} \mathrm{kg}^{-1}$ DW at $10-20 \mathrm{~cm}$ depth while in plants ranged between 1.04-255 $\mathrm{mg} \mathrm{kg}{ }^{-1}$ DW. Cd content in soil was $29 \mathrm{mg} \mathrm{kg}^{-1}$ at $0-10 \mathrm{~cm}$ depth and $23 \mathrm{mg} \mathrm{kg}^{-1}$ at $10-20 \mathrm{~cm}$ depth. In plants, Cd content ranged between 0.015-4.81 mg kg-1 DW. In Sasar district and in Center area moderate soil pollution with $\mathrm{Pb}$ was found. Data analysis indicated significant correlations between $\mathrm{Pb}$ and $\mathrm{Cd}$ contents in the superficial soil level of $0-10 \mathrm{~cm}$ as well as between $\mathrm{Pb}$ and $\mathrm{Cd}$ contents in soil at the depth of 10-20 cm, showing that the powder coming from the metallurgical plants is the common source of these elements. Conclusion: The study shows a non-uniform spread of $\mathrm{Pb}$ and $\mathrm{Cd}$ both in soil and plants in Baia Mare city, due to anthropogenic influences. The highest contents of these elements were found in Ferneziu area in soil as well as in plant samples. Remediation measures are required prevalently in Ferneziu district around the lead smelter.
\end{abstract}

Key words: Lead, cadmium, cluster analysis, principal component analysis, metallurgical plants, soil pollution, Baia Mare, Ferneziu district

\section{INTRODUCTION}

The town of Baia Mare used to be an important nonferrous metallurgical center where heavy metals like $\mathrm{Cu}$ and $\mathrm{Pb}$ have been extracted and processed from centuries. Due to the aerial emissions from a metallurgical plant "Romplumb" that has been processing lead, located in the Ferneziu district, as well as from "Cuprom" plant that has been processing copper, located in the eastern part of the city, the soil in Baia Mare area is highly polluted with heavy metals: $\mathrm{Pb}, \mathrm{Cd}, \mathrm{Cu}, \mathrm{Zn}$ (Damian et al., 2008; Levei et al., 2009) and also with As (Oprea et al., 2010) and (Senila et al., 2011).

$\mathrm{Pb}$ and $\mathrm{Cd}$ in soil represent a major environmental and human health concern due to their high toxicity, low biodegradability and cumulative tendency. $\mathrm{Pb}$ and $\mathrm{Cd}$ are not essential microelements and their presence in the environment in concentrations that exceed the normal values may seriously affect living organisms

Corresponding Author: Gabriela Oprea, Department of Chemistry and Biology, Faculty of Sciences, North University of Baia Mare, 430083, Baia Mare, Romania 
and human health. The bone lead deposits alter its mineralization processes, lead being in competition with the intra- and extra-cell calcium ions (Jelea and Jelea, 2009). As evidenced by a clinical study focusing on the health of the "Romplumb" employees, exposure to high $\mathrm{Pb}$ concentrations leads to hem synthesis alteration and low number of leukocytes (Jelea and Jelea, 2007). Heavy metals can be absorbed from the soil by plants affecting living organisms (Duffy et al., 2009) and entering the food chain. The $\mathrm{Pb}$ and $\mathrm{Cd}$ content in plants are influenced by their content in soil, the $\mathrm{pH}$ of the soil and the presence of other microelements (Akan et al., 2009).

The normal content of $\mathrm{Pb}$ in soil is $20 \mathrm{mg} \mathrm{kg}^{-1}$, as defined by the Romanian regulations. This value is found in unpolluted agricultural and forestry soils but in polluted or industrial areas is much higher: 108-399 mg $\mathrm{kg}^{-1}$ (Miclean et al., 2009). In non-polluted area the $\mathrm{Pb}$ concentrations in vegetables and fruit range between 0.07 and $0.46 \mathrm{mg} \mathrm{kg}^{-1} \mathrm{DW}$ (Bordean et al., 2011). In dehydrated vegetables $\mathrm{Pb}$ content has to be lower than 3 $\mathrm{mg} \mathrm{kg}{ }^{-1}$ for safe consumption as it is stipulated by the Romanian regulations but in polluted areas concentrations of 0.03-6.66 $\mathrm{mg} \mathrm{kg}^{-1}$ (Akan et al., 2009) were reported in various parts of the plant (roots, steam and leaf). The normal content of $\mathrm{Cd}$ in soil is $1 \mathrm{mg} \mathrm{kg}^{-1}$ as defined by the Romanian regulations. Concentrations of $0.15-4.3 \mathrm{mg} \mathrm{kg}^{-1}$ in soils were reported in polluted areas (Miclean et al., 2009). The Cd content has to be lower than $0.5 \mathrm{mg} \mathrm{kg}^{-1}$ in dehydrated vegetables according to Romanian legislation. In non-polluted areas the concentrations of $\mathrm{Cd}$ in vegetables and fruit range from $0.02-0.11 \mathrm{mg} \mathrm{kg}^{-1}$ (Bordean et al., 2011). In polluted areas the content of $\mathrm{Cd}$ in plants is usually higher: 0.01-2.31 $\mathrm{mg} \mathrm{kg}^{-1}$ in vegetables (Miclean et al., 2009).

The $\mathrm{Pb}$ and $\mathrm{Cd}$ content in soil and plants in several areas in Baia Mare town were determined. The investigated areas were: Ferneziu district, Săsar district and the area located around the centre of the town, called in the present study as Center. Previous studies performed in these areas have found high concentrations of heavy metals in the soil, as a consequence of the falling dust containing metals from direct, diffuse or fugitive emissions from the metallurgical plants (Levei et al., 2009; Damian et al., 2008). The experimental data was discussed in comparison with data from Dura reference area that is located in the western part of the city, far away from the metallurgical plants. Data concerning $\mathrm{Pb}$ and $\mathrm{Cd}$ contents in soil and in plants were assessed and correlations between contents in soil at the depth of 010 and $10-20 \mathrm{~cm}$ and in plants and the soil main characteristics ( $\mathrm{pH}$ and conductivity of the aqueous soil suspension and also, total organic carbon content of the soil) were established.
Principal component analysis was applied in order to refine the data, to improve the significance and to reduce the number of variables. Principal components analysis is often applied in the environmental studies where a high number of data and parameters have to be processed and correlated (Yisa, 2010; Bai et al., 2010; Hamzah et al., 2011).

This study deals with the investigation of soil and plant in Baia Mare city in order to evaluate the occurrence of $\mathrm{Pb}$ and $\mathrm{Cd}$, as a premise for future studies on determining the coefficient of transfer from soil to plants for these elements, as an indicator of the real degree of the soil pollution and threath to human health.

\section{MATERIALS AND METHODS}

Location of the studied area: The soil samples were collected from three areas in Baia Mare city: Ferneziu district, which is located in the proximity of a lead smelter, Săsar district which is located along the Săsar River in the preferential direction of the wind coming from the metallurgical plant producing lead and the Central area with its surroundings (referred as Center). Dura area located in a less polluted hilly area, in the west part of the town was considered as reference area. The investigated areas and the pollution sources have been marked on the map in Fig. 1.

Soil and plants sampling: Samples of soil and plants from the residential part of Ferneziu and Săsar districts, Center and Dura area were collected. Ten soil samples were collected from each area at the depth of 0-10 and 10-20 cm during July-August 2009 from several locations in gardens and residential areas. These depths were selected aiming to evaluate the ongoing inputs of $\mathrm{Pb}$ and $\mathrm{Cd}$ in the soil. A GPS was used to get the coordinates of each sampling location. At the same time, plants had been collected growing on the soil from where the soil samples had been drawn. The plant samples from the garden soils were vegetables used in human consumption such as onion (Allium cepa) and dill (Anethum graveolens); while for the other locations the plant samples had been collected from the spontaneous flora (Agrostis, Agropirum, Trifolium repens, Urtica dioica). The aerial parts of plants were collected except onion where the bulb was collected. The soil samples were crushed and dried at room temperature for $48 \mathrm{~h}$, then passed through a $2 \mathrm{~mm}$ sieve. The plant samples were washed in distilled water and then dried at $80^{\circ} \mathrm{C}$ for $24 \mathrm{~h}$ and grounded to obtain a homogenized powder (Oprea et al., 2010; Senila et al., 2011). The soil and plant samples were digested in aqua regia following the method from ISO 11466: 1999. 
Pb and Cd analysis: The determination of $\mathrm{Cd}$ and $\mathrm{Pb}$ in soils and plant samples was done using the inductively coupled plasma atomic emission spectrometer, ICP-AES, with simultaneous detection Optima 5300 DV (Perkin Elmer), with axial and radial dual vision. All reagents used (65\% nitric acid, $32 \%$ hydrochloric acid) were purris p.a. quality (Merck). For external calibration, $\mathrm{Pb}$ and $\mathrm{Cd}$ stock solutions of $1000 \mu \mathrm{g} \mathrm{mL}^{-1}$ (Merck) were used. All dilutions were made with $2 \% \mathrm{HNO}_{3}$ (Merck). A certified soil reference material (SRM 2709, San Joaquin Soil and NIST) was used to evaluate the accuracy of the extraction procedures.

Determination of soil characteristics (pH, electric conductivity and total organic carbon content): The $\mathrm{pH}$ measurement of the aqueous suspension 1:5 (mass/volume) of the $<2 \mathrm{~mm}$ fraction of the soil samples was performed using a Consort $2000 \mathrm{pH}$-meter equipped with a combined $\mathrm{pH}$ electrode.

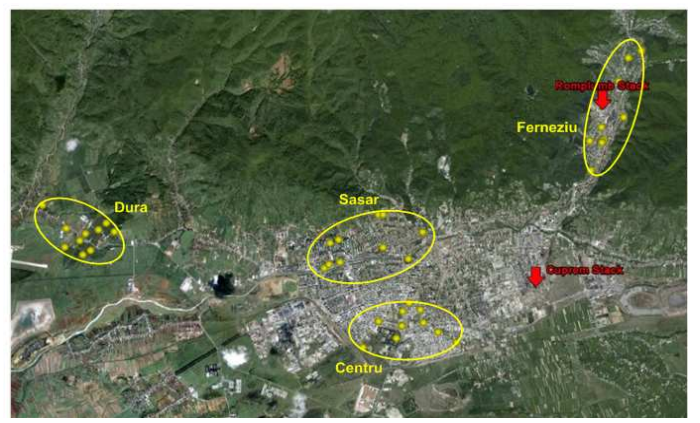

Fig. 1: The satellite image showing the location of the sampling points and the main pollution sources in Baia Mare area
Soil suspension was shaken for $2 \mathrm{~h}$ before measuring the $\mathrm{pH}$. The electric conductivity of the soil solution was determined with a WTW 2008 conductometer in the supernatant of the soil suspension used to measure the $\mathrm{pH}$. The Total Organic Carbon content (TOC) in soil samples was determined with a multi N/C 2100 Analytik Jena analyzer.

Data analysis: Statistical analysis of data was performed using the statistical tools offered by Windows Excel and the Statistica software package (version 10) from Stat Soft. The differences were considered significant if $\mathrm{p}<0.05$. Each variable was standardized by subtracting the mean of sample and then dividing by the standard deviation.

Comparisons with the Romanian regulations were discussed for metals contents both in soil samples (NV-normal content, ATV-alert threshold value) and in plant samples (MAL-maximum allowable limit).

\section{RESULTS}

$\mathrm{Pb}$ and $\mathrm{Cd}$ contents in soil at $0-10$ and $10-20 \mathrm{~cm}$ depth and in plant samples in the investigated areas (Ferneziu district, Săsar district, Center and Dura as reference area) are summarized in Table 1. Results are reported on dry matter basis.

The characteristics of the soil could influence the uptake of $\mathrm{Pb}$ and $\mathrm{Cd}$ in plants. Therefore the investigated characteristics of soil samples in the studied areas: $\mathrm{pH}$ and conductivity of the soil extract and total organic carbon content are presented in Table 2.

Table 1: $\mathrm{Pb}$ and $\mathrm{Cd}$ contents in soil (top level 0-10 $\mathrm{cm}$ depth and 10-20 $\mathrm{cm}$ depth) and in plant samples in the studied areas in Baia Mare zone

\begin{tabular}{|c|c|c|c|c|c|c|c|}
\hline \multirow[b]{2}{*}{ Area } & \multirow[b]{2}{*}{ Parameter } & \multicolumn{3}{|l|}{$\mathrm{Pb}(\mathrm{mg} / \mathrm{kg})$} & \multicolumn{3}{|l|}{$\mathrm{Cd}(\mathrm{mg} / \mathrm{kg})$} \\
\hline & & Soil $(0-10 \mathrm{~cm})$ & Soil $(10-20 \mathrm{~cm})$ & Plants & Soil $(0-10 \mathrm{~cm})$ & Soil $(10-20 \mathrm{~cm})$ & Plants \\
\hline Ferneziu & Average & 4400.0 & 3100.0 & 30.000 & 29.00 & 23.00 & 1.400 \\
\hline \multirow[t]{3}{*}{$\mathrm{N}=10$} & Standard deviation & 5600.0 & 2500.0 & 80.000 & 35.00 & 19.00 & 1.300 \\
\hline & Minim & 115.0 & 105.0 & 1.040 & 0.15 & 0.15 & 0.015 \\
\hline & Maxim & 19195.0 & 6521.0 & 255.000 & 113.00 & 56.50 & 4.810 \\
\hline Săsar & Average & 720.0 & 620.0 & 2.900 & 2.50 & 2.10 & 0.700 \\
\hline \multirow[t]{3}{*}{$\mathrm{N}=10$} & Standard deviation & 500.0 & 410.0 & 3.500 & 3.30 & 2.00 & 0.700 \\
\hline & Minim & 257.0 & 125.0 & 0.550 & 0.05 & 0.40 & 0.016 \\
\hline & Maxim & 1647.0 & 1334.0 & 12.100 & 11.65 & 4.75 & 2.580 \\
\hline Center & Average & 260.0 & 280.0 & 1.900 & 0.49 & 0.80 & 0.120 \\
\hline \multirow[t]{3}{*}{$\mathrm{N}=10$} & Standard deviation & 150.0 & 150.0 & 1.600 & 0.34 & 0.77 & 0.070 \\
\hline & Minim & 14.3 & 90.0 & 0.023 & 0.05 & 0.10 & 0.015 \\
\hline & Maxim & 512.0 & 532.0 & 5.100 & 1.15 & 2.83 & 0.210 \\
\hline Dura & Average & 75.0 & 54.0 & 1.700 & 0.18 & 0.13 & 0.360 \\
\hline \multirow[t]{3}{*}{$\mathrm{N}=10$} & Standard deviation & 9.0 & 15.0 & 0.190 & 0.16 & 0.15 & 0.300 \\
\hline & Minim & 65.6 & 34.0 & 1.480 & 0.02 & 0.02 & 0.084 \\
\hline & Maxim & 90.2 & 81.5 & 2.120 & 0.50 & 0.42 & 0.900 \\
\hline \multirow{2}{*}{\multicolumn{2}{|c|}{$\begin{array}{l}\text { ATV for soils with sensitive land-use } \\
\text { MAL in dehydrated vegetables }\end{array}$}} & & 50.0 & & 3.00 & & \\
\hline & & & 3.00 & & 0.50 & & \\
\hline
\end{tabular}


Am. J. Environ. Sci., 7 (5): 402-408, 2011

Table 2: Characteristics of soil samples ( $\mathrm{pH}$, conductivity and Total Organic Carbon content TOC) in the studied areas in Baia Mare city

\begin{tabular}{|c|c|c|c|c|c|c|}
\hline \multirow[b]{2}{*}{ Area } & \multirow[b]{2}{*}{ Parameter } & \multicolumn{2}{|l|}{$\mathrm{pH}$} & \multicolumn{2}{|c|}{ Conductivity of the soil extract, $\mu \mathrm{S} / \mathrm{cm}$} & \multirow{2}{*}{$\begin{array}{l}\text { TOC, }, \mathrm{g} / \mathrm{kg} \\
0-10 \mathrm{~cm}\end{array}$} \\
\hline & & $0-10 \mathrm{~cm}$ & $10-20 \mathrm{~cm}$ & $0-10 \mathrm{~cm}$ & $10-20 \mathrm{~cm}$ & \\
\hline Ferneziu & Average & 6.80 & 6.80 & 129.25 & 99.27 & 38.25 \\
\hline \multirow[t]{3}{*}{$\mathrm{N}=10$} & Standard deviation & 0.60 & 0.70 & 39.49 & 33.20 & 9.44 \\
\hline & Minim & 5.70 & 5.30 & 53.60 & 45.00 & 23.92 \\
\hline & Maxim & 7.50 & 7.70 & 202.00 & 151.90 & 50.62 \\
\hline Săsar & Average & 6.00 & 6.20 & 60.14 & 78.76 & 53.75 \\
\hline \multirow[t]{3}{*}{$\mathrm{N}=10$} & Standard deviation & 0.90 & 0.90 & 29.07 & 45.04 & 42.40 \\
\hline & Minim & 4.50 & 4.90 & 31.90 & 26.00 & 22.25 \\
\hline & Maxim & 7.20 & 7.70 & 118.90 & 151.90 & 169.30 \\
\hline Center & Average & 7.20 & 7.30 & 85.21 & 79.20 & 18.30 \\
\hline \multirow[t]{3}{*}{$\mathrm{N}=10$} & Standard deviation & 0.70 & 0.50 & 18.28 & 27.49 & 4.60 \\
\hline & Minim & 6.20 & 6.70 & 49.40 & 43.40 & 8.05 \\
\hline & Maxim & 8.30 & 8.30 & 117.10 & 118.90 & 23.80 \\
\hline Dura & Average & 5.88 & 5.97 & 36.98 & 52.75 & 22.04 \\
\hline \multirow[t]{3}{*}{$\mathrm{N}=10$} & Standard deviation & 0.15 & 0.18 & 4.70 & 25.48 & 1.91 \\
\hline & Minim & 5.60 & 5.60 & 26.00 & 26.00 & 19.23 \\
\hline & Maxim & 6.10 & 6.20 & 42.50 & 117.10 & 25.32 \\
\hline
\end{tabular}

\section{DISCUSSION}

$\mathrm{Pb}$ and $\mathrm{Cd}$ content in soil and plants were quite different for one area to another.

In Ferneziu district the highest $\mathrm{Pb}$ contents in soil were found both at $0-10 \mathrm{~cm}$ and $10-20 \mathrm{~cm}$ depth. The average content of $\mathrm{Pb}$ in soil at $0-10 \mathrm{~cm}$ is 88 times higher than the alert threshold value; at $10-20 \mathrm{~cm}$ the average $\mathrm{Pb}$ concentration was 62 times higher than the alert threshold value.

High $\mathrm{Pb}$ contents in soil were determined also in Săsar district: at the level of $0-10 \mathrm{~cm}$ the average $\mathrm{Pb}$ concentration exceeds 14.4 times the alert threshold value while at the depth of $10-20 \mathrm{~cm}$ the average $\mathrm{Pb}$ concentration exceeds 12.4 times the alert threshold value. In the Center area, the average $\mathrm{Pb}$ content in soil exceeds 5.2 times the alert threshold value at $0-10 \mathrm{~cm}$ depth and 5.6 times at 10-20 cm depth.

Comparing the concentrations of $\mathrm{Pb}$ in soil at the two depths $(0-10$ and $10-20 \mathrm{~cm})$ it was found that $\mathrm{Pb}$ concentration is higher in the top level in Ferneziu and Săsar districts indicating the ongoing soil pollution while in the Center there is a reverse situation, probably because of the already historical soil pollution ("Cuprom" metallurgical plant that used to process copper materials is closed since 2008).

High concentrations of $\mathrm{Pb}$ in plants in Ferneziu district were also found in our study. The average content of $\mathrm{Pb}$ in plants was almost 18 times higher in this district, while in Săsar district 1.7 times higher than in the reference area Dura. In Center the average $\mathrm{Pb}$ content in plants was close to the average value found in the reference area.

Regarding Cd, the highest soil concentrations were determined in Ferneziu district. $\mathrm{Cd}$ average concentration exceeds 9.66 times the alert threshold value $\left(3 \mathrm{mg} \mathrm{kg}^{-1}\right)$ at $0-10 \mathrm{~cm}$ depth and 7.66 times at $10-20 \mathrm{~cm}$ depth. In Săsar district and in Center the average $\mathrm{Cd}$ contents in soil are lower than the alert threshold value.

In the Ferneziu district the average content of $\mathrm{Cd}$ in plants was 3.8 times higher than in the reference area, while in Săsar district it was 2 times higher. In Center, Cd content in plants was lower than in the reference area.

We have calculated the Pearson's correlation coefficients considering the following indicators (characteristics): $\mathrm{Pb}$ and $\mathrm{Cd}$ contents in soil at the two depths $(0-10 \mathrm{~cm}$ and $10-20 \mathrm{~cm}), \mathrm{Pb}$ and $\mathrm{Cd}$ in plants and $\mathrm{pH}$ of soil extract. The logarithm values were used for metal concentration in soil and plants in order to make the variables normal. The matrix of Pearson's correlation coefficients is presented in Table 3 .

The strongest correlations $(\mathrm{p}<0.05)$ are between $\mathrm{Cd}$ in soil at the depth of $0-10 \mathrm{~cm}$ and at the depth of 10-20 $\mathrm{cm}$ : 0.96. Similar strong correlations were found for $\mathrm{Pb}$ in soil at the two depths and also for $\mathrm{pH}$ showing the similar composition of the two layers.

Good correlations $(\mathrm{p}<0.05)$ were found between the $\mathrm{Pb}$ and $\mathrm{Cd}$ contents in the superficial soil level of $10-20 \mathrm{~cm}(0.96)$ as well as between $\mathrm{Pb}$ and $\mathrm{Cd}$ contents in soil at the depth of $0-10 \mathrm{~cm}(0.90)$, suggesting a common source of these elements: the powder emitted by the metallurgical plants.

The Cd content in soil at $0-10 \mathrm{~cm}$ depth is quite highly correlated with that of $10-20 \mathrm{~cm}$ depth (0.90); for the $\mathrm{Pb}$ content the corresponding correlation is weaker (0.76) but also significant. The correlation between the $\mathrm{Pb}$ and $\mathrm{Cd}$ content in plants is higher for the superficial soil level of $0-10 \mathrm{~cm}$ depth $(\mathrm{Pb} 0.89$ and $\mathrm{Cd} \mathrm{0.84)} \mathrm{than} \mathrm{for} \mathrm{the} \mathrm{deepest} \mathrm{level} \mathrm{of} 10-20 \mathrm{~cm}(\mathrm{~Pb}$ 0.31 and $\mathrm{Cd}$ 0.68). 
Am. J. Environ. Sci., 7 (5): 402-408, 2011

Table 3: Pearson's correlation coefficients ( $\mathrm{r}$ ) of $\mathrm{Pb}$ and $\mathrm{Cd}$ contents in soil and plants and the investigated soil characteristics: $\mathrm{pH}$ and electric conductivity of soil extract and total organic carbon, Baia Mare area $(\mathrm{N}=40)$

\begin{tabular}{|c|c|c|c|c|c|c|c|c|}
\hline & $\begin{array}{l}\mathrm{Pb} \text { in soil, } \\
0-10 \mathrm{~cm}\end{array}$ & $\begin{array}{l}\mathrm{Pb} \text { in soil, } \\
10-20 \mathrm{~cm}\end{array}$ & $\begin{array}{l}\mathrm{Pb} \text { in } \\
\text { plants }\end{array}$ & $\begin{array}{l}\text { Cd in soil, } \\
0-10 \mathrm{~cm}\end{array}$ & $\begin{array}{l}\text { Cd in soil, } \\
10-20 \mathrm{~cm}\end{array}$ & $\mathrm{Cd}$ in plants & $\mathrm{pH}$, plants & $\mathrm{pH}, 10-20 \mathrm{~cm}$ \\
\hline $\mathrm{Pb}$ in soil, & 1.00 & 0.94 & $0.45^{*}$ & $0.90^{*}$ & $0.90 *$ & $0.39^{*}$ & -0.09 & -0.21 \\
\hline $\begin{array}{l}0-10 \mathrm{~cm} \mathrm{~Pb} \text { in soil, } \\
10-20 \mathrm{~cm}\end{array}$ & & 1.00 & $0.35 *$ & $0.91 *$ & $0.96^{*}$ & $0.34 *$ & 0.04 & -0.05 \\
\hline & & & 1.00 & $0.39 *$ & $0.36^{*}$ & $0.47 *$ & -0.15 & -0.25 \\
\hline $\begin{array}{l}\text { Cd in soil, } \\
0-10 \mathrm{~cm}\end{array}$ & & & & 1.00 & $0.89 *$ & $0.48 *$ & -0.11 & -0.23 \\
\hline $\begin{array}{l}\text { Cd in soil, } \\
10-20 \mathrm{~cm}\end{array}$ & & & & & 1.00 & 0.29 & 0.02 & -0.09 \\
\hline $\mathrm{Cd}$ in plants & & & & & & 1.00 & $-0.33 *$ & $-0.42 *$ \\
\hline $\begin{array}{l}\mathrm{pH}, \\
0-10 \mathrm{~cm} \\
\mathrm{pH}, \\
10-20 \mathrm{~cm}\end{array}$ & & & & & & & 1.00 & $\begin{array}{l}0.95 * \\
1.00\end{array}$ \\
\hline
\end{tabular}

Table 4: The eigenvalues of the correlation matrix

\begin{tabular}{lllll}
\hline $\begin{array}{l}\text { Number of } \\
\text { variables }\end{array}$ & Eigenvalue & $\begin{array}{l}\text { Total } \\
\text { variance }(\%)\end{array}$ & $\begin{array}{l}\text { Cumulative } \\
\text { eigenvalue }\end{array}$ & $\begin{array}{l}\text { Cumulative } \\
\text { variance }(\%)\end{array}$ \\
\hline 1 & 5.3000 & 48.188 & 5.30100 & 48.188 \\
2 & 2.4900 & 22.639 & 7.79100 & 70.828 \\
3 & 1.4170 & 12.888 & 9.20900 & 83.717 \\
4 & 0.7630 & 6.943 & 9.97266 & 90.661 \\
5 & 0.6120 & 5.568 & 10.58500 & 96.230 \\
6 & 0.2000 & 1.822 & 10.78600 & 98.052 \\
7 & 0.1070 & 0.981 & 10.89400 & 99.033 \\
8 & 0.0480 & 0.441 & 10.94200 & 99.474 \\
9 & 0.0377 & 0.342 & 10.98000 & 99.817 \\
10 & 0.0180 & 0.169 & 10.99800 & 99.987 \\
11 & 0.0010 & 0.013 & 11.00000 & 100.000 \\
\hline
\end{tabular}

Table 5: Loadings for the first four factors

\begin{tabular}{|c|c|c|c|c|}
\hline Variable & & Factor 2 & Factor 3 & Factor 4 \\
\hline $\mathrm{Cd}$ in soil $(0-10 \mathrm{~cm})$ & $0.972 *$ & * $\quad 0.029$ & 0.180 & 0.032 \\
\hline $\mathrm{Cd}$ in soil $(10-20 \mathrm{~cm})$ & $0.910^{*}$ & 0.207 & 0.068 & 0.166 \\
\hline $\mathrm{Cd}$ in plants & $0.891 *$ & -0.215 & -0.101 & -0.040 \\
\hline $\mathrm{Pb}$ in soil $(0-10 \mathrm{~cm})$ & $0.959^{*}$ & 0.020 & 0.241 & -0.008 \\
\hline $\mathrm{Pb}$ in soil $(10-20 \mathrm{~cm})$ & $0.814 *$ & 0.217 & 0.003 & 0.371 \\
\hline $\mathrm{Pb}$ in plants & $0.795 *$ & -0.110 & 0.352 & -0.272 \\
\hline $\mathrm{pH}(0-10 \mathrm{~cm})$ & -0.168 & $0.954 *$ & 0.143 & 0.022 \\
\hline $\mathrm{pH}(10-20 \mathrm{~cm})$ & -0.275 & $0.922 *$ & 0.066 & 0.035 \\
\hline Conductivity $(0-10 \mathrm{~cm})$ & 0.402 & $0.716^{*}$ & -0.468 & -0.075 \\
\hline Conductivity $(10-20 \mathrm{~cm})$ & 0.448 & 0.099 & $-0.576^{*}$ & $-0.598 *$ \\
\hline TOC $(0-10 \mathrm{~cm})$ & 0.219 & -0.239 & $-0.782 *$ & 0.396 \\
\hline
\end{tabular}

A quite good correlation of $\mathrm{Pb}$ and $\mathrm{Cd}$ in plants was found (0.47) suggesting a comparable behavior of the plants regarding the uptake of these two elements both toxic.

There is no correlation between $\mathrm{pH}$ and the content of the studied metals $(\mathrm{Pb}$ and $\mathrm{Cd})$ in soil. A weak negative correlation was found between $\mathrm{Cd}$ content in plants and the $\mathrm{pH}$ of the soil at the depth of $10-20 \mathrm{~cm}$ : 0.42 showing that the uptake of $\mathrm{Cd}$ by plants is favored by the acidic soil $\mathrm{pH}$.
The experimental data were statistically analyzed by cluster method and principal component analysis using the Statistica software package. These methods were applied after the standardization of the data in order to make them comparable.

The cluster analysis is aimed to highlight the similarity between data or variables. In our study the 11 investigated variables are: $\mathrm{Cd}$ in soil at top level of 0-10 $\mathrm{cm}, \mathrm{Cd}$ in soil at $10-20 \mathrm{~cm}$ depth, $\mathrm{Cd}$ in plants, $\mathrm{Pb}$ in soil at the same depths, $\mathrm{Pb}$ in plants, $\mathrm{pH}$ and conductivity of the soil extract for the two depths and Total Organic Carbon content (TOC) which was measured only for the depth of $0-10 \mathrm{~cm}$.

The dendogram for these variables built by Ward's method using Euclidean distance is shown in Fig. 2. Analyzing the dendogram, two main clusters are observed: one of them groups the $\mathrm{Pb}$ and $\mathrm{Cd}$ contents in plants and in soil and the other groups the $\mathrm{pH}$ and the conductivity at the two depths and also the total organic carbon content of soil samples. The results are in good agreement with the previously calculated correlations (Table 2).

The principal component analysis was carried out in order to find a few components that are accounting for the major variation within our data. Each factor is a weighted linear combination of the original variables. The eigenvalues of the correlation matrix are listed in Table 4 . The first three principal components account for almost $84 \%$ of the variance in the data and therefore they accurately describe the majority of the system (Table 4).

Table 5 shows the contributions (loadings) of different variables to the principal components. The maximum contributions to the first component are $\mathrm{Cd}$ and $\mathrm{Pb}$ concentrations in soil (at both depths: $0-10$ and $10-20 \mathrm{~cm}$ ) and in plants; their contributions are close and can be explained by the high degree of correlation between these characteristics of the system. 


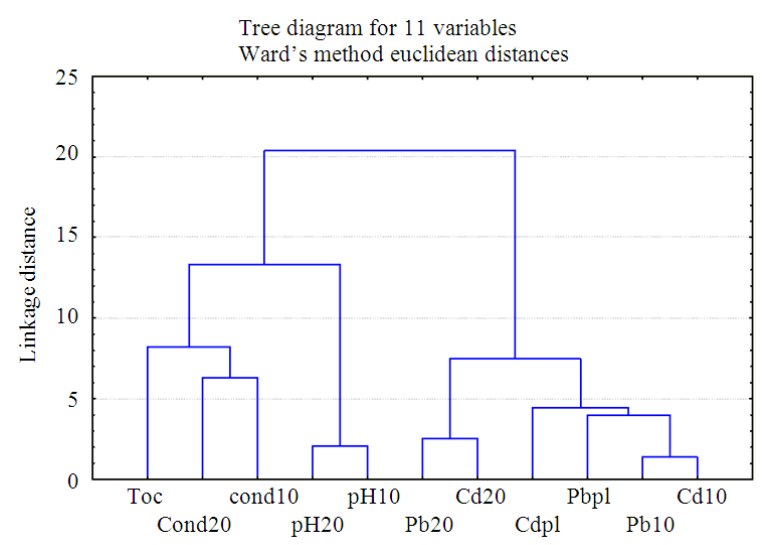

Fig. 2: Dendogram of the variables using Ward's method (the index 10 indicates the soil depth of $0-10 \mathrm{~cm}$ and the index 20 indicates the soil depth of 10-20 cm; Cdpl means $\mathrm{Cd}$ in plants, $\mathrm{Pbpl}$ means $\mathrm{Pb}$ in plants)

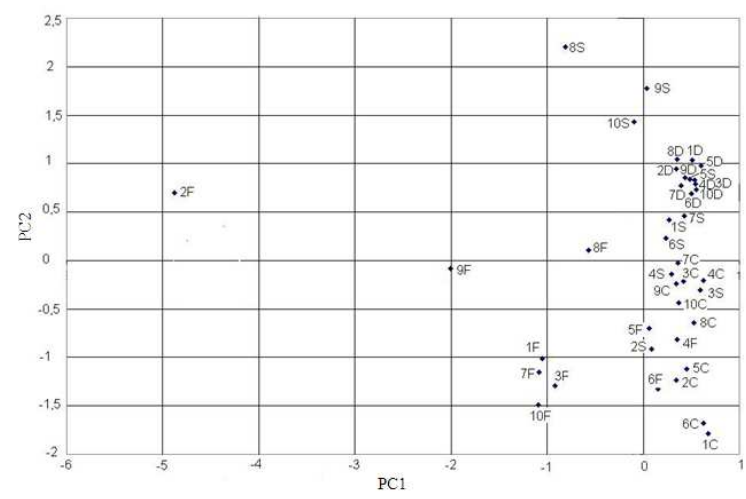

Fig. 3: Scatter plot of scores corresponding to the first two principal components PC 1 and PC 2 FFerneziu district; S-Săsar district; C-Central area of Baia Mare city; D-Dura area

Smaller contributions have been found for the conductivity of the soil extract. Conductivity and $\mathrm{pH}$ and of the soil extract for the superficial level $(0-10 \mathrm{~cm}$ depth) contribute predominantly to the second principal component, while the soil conductivity at $10-20 \mathrm{~cm}$ depth and Total Organic Carbon content of soil (TOC) are prevalent in the third principal component. The unique parameter whose maximum contribution appears in the fourth principal component is the conductivity at $10-20 \mathrm{~cm}$ depth.

Figure 3 shows the plot of scores corresponding to the first two principal components for the soil and plants samples collected from the four areas of Baia Mare zone (40 sampling locations). The point $2 \mathrm{~F}$ is located in the residential area very close (around 300 m) to "Romplumb" lead processing plant. That explains the distinct character of this point.

There is a strong grouping for the representative points of the sample from the less polluted area, Dura showing the control of natural factors like parent material with minor influences from anthropogenic activities. On the other side, the points corresponding to the sample from the most polluted Ferneziu district are much more widespread, but in the same time clearly distinctive when compared to the samples from the other areas and that is indicating anthropogenic influences. The points corresponding to the samples from Center are closer to those from Dura area showing a similarity and suggesting that in the Central zone the soil and plants are less contaminated with $\mathrm{Pb}$ and $\mathrm{Cd}$ than in Săsar or Ferneziu district. The results were in accordance with the previous studies in Baia Mare area (Damian et al., 2008; Oprea et al, 2010).

\section{CONCLUSION}

$\mathrm{Pb}$ and $\mathrm{Cd}$ contents in soil and in plants in several districts of Baia Mare town were investigated and compared with the reference area, Dura.

The study shows a non-uniform (irregular) spread of these elements highlighting anthropogenic influences. The highest contents of these elements both in soils samples and in plants were found in Ferneziu area, but also in some locations in Săsar district.

Cluster analysis and principal component analysis confirm the different degree of soil pollution and plants contamination by $\mathrm{Pb}$ and $\mathrm{Cd}$ in the four areas that have been studied. Parameters that seem to best characterize the soil pollution are the concentration of pollutants $(\mathrm{Pb}$ and $\mathrm{Cd}$ ) in soil and plants and also the soil $\mathrm{pH}$. The conductivity of soil extract and total organic carbon are not characteristics for the soil pollution and plant contamination with $\mathrm{Cd}$ and $\mathrm{Pb}$.

Because of the toxicity of these elements urgent remediation measures are required prevalently for those areas located in the close vicinity of the pollution source.

\section{ACKNOWLEDGEMENT}

The present researches were supported by the Romanian Ministry of Education and Research, within the PNCDI II Program (Project CISPPA no. 52157/2008). We thank for the financial support.

We thank Professor Ossi Horovitz from Babes Bolyai University in Cluj Napoca, Romania for the help in statistical analysis of data. 


\section{REFERENCES}

Akan, J.C., F.I.A. Abdulrahman, V.O. Ogugbuaja and J.T. Ayodele, 2009. Heavy metals and anion levels in some samples of vegetable grown within the vicinity of challawa industrial area, Kano State, Nigeria. Am. J. Applied Sci., 6: 534-542. DOI: 10.3844/ajassp.2009.534.542

Bai, J., B. Cui, Z. Yang, X. Xu and Q. Ding et al., 2010. Heavy metal contamination of cultivated wetland soils along a typical plateau lake from southwest China. Environ. Earth Sci., 59: 17811788. DOI: $10.1007 / \mathrm{s} 12665-009-0160-\mathrm{z}$

Bordean, D.M., I. Gergen, I. Gogoasa, G. Oprea and L. Pirvulescu et al., 2011. Mathematical model evaluation of heavy metal contamination in vegetables and fruits. J. Food, Agric. Environ., 9: 680-683.

Damian, F., G. Damian, R. Lacatusu, G. Macovei and G. Iepure et al., 2008. Soils from the Baia Mare zone and the heavy metals pollution. Carpth. J. Earth Environ. Sci., 3: 85-98.

Duffy, L.K., M.W. Oehler, S.R.T. Bowyer and V.C. Bleich, 2009. Mountain sheep: An environmental epidemiological survey of variation in metal exposure and physiological biomarkers following mine development. Am. J. Environ. Sci., 5: 295302. DOI: 10.3844/ajessp.2009.295.302

Jelea, S.G. and M. Jelea, 2007. Effects of polluting substances on risk categori molten and agglomerfation workers from "Romplumb Society" Baia Mare. Carpth. J. Earth Environ. Sci.

Jelea, S.G. and M. Jelea, 2009. Effects of subacute treatment with lead acetate on the mineral constituents from femur and tibia. Carpth. J. Earth Environ. Sci., 4: 61-68.
Hamzah, Z., S.D. Riduan and A. Saat, 2011. Vertical profile of $\mathrm{C}, \mathrm{N}, \mathrm{P}, \mathrm{K}$ and radionuclides in soil collected from highland tea plantation areas. Am. J. Applied Sci., 8: 1307-1313. DOI: DOI: 10.3844/ajassp.2011.1307.1313

Levei, E., T. Frentiu, M. Ponta, M. Senila and M. Miclean et al., 2009. Characterisation of soil quality and mobility of $\mathrm{Cd}, \mathrm{Cu}, \mathrm{Pb}$ and $\mathrm{Zn}$ in the Baia Mare area Northwest Romania following the historical pollution. Int. J. Environ. Analytical Chem., $\quad$ 89: 635-649, $\quad$ DOI: 10.1080/03067310902792586

Miclean, M., E.A. Levei, M. Senila, C. Roman and E. Cordos, 2009. Assessment of $\mathrm{Cu}, \mathrm{Pb}, \mathrm{Zn}$ and $\mathrm{Cd}$ availability to vegetable species grown in the vicinity of tailing deposits from Baia Mare Area. Rev. Chim., 60: 1-4.

Oprea, G., A. Michnea, C. Mihali, M. Senila and C. Roman et al., 2010. Arsenic and Antimony content in soil and plants from baia mare area, Romania. Am. J. Environ. Sci., 6: 33-40. DOI: 10.3844/ajessp.2010.33.40

Senila, M., E. Levei, L. Senila, O. Cadar and G. Oprea et al., 2011. Comparative study of mercury determination in soil and vegetable by methods based on thermal decomposition-AAS and wet digestion CV-AFS. Studia Universitatis.

Yisa, J., 2010. Heavy metals contamination of roaddeposited sediments. Am. J. Applied Sci., 7: 12311236. DOI: $10.3844 /$ ajassp.2010.1231.1236 